\title{
Risk Factors for Non-Alcoholic Fatty Liver Disease Among the Patients Admitted to a Teaching Hospital in Sri Lanka: Case Control study
}

\section{Ayoma Nissanka}

Ministry of Health

Chrishantha Abeysena ( $\sim$ chrishanthaabeysena@yahoo.com )

University of Kelaniya https://orcid.org/0000-0001-5456-8281

\section{Research article}

Keywords: Alcohol, case control, fatty liver, physical activities, risk factors,

Posted Date: August 21st, 2020

DOI: https://doi.org/10.21203/rs.3.rs-54768/v1

License: (c) (i) This work is licensed under a Creative Commons Attribution 4.0 International License.

Read Full License 


\section{Abstract}

Background: The burden of Non-Alcoholic Fatty Liver Disease (NAFLD) was rising globally. It was the disease condition where there was increase fat deposition $(\geq 5 \%)$ in the hepatic cells. The objective of this study was to determine the risk factors for NAFLD among the patients admitted to a Teaching Hospital in Sri Lanka.

Methods: A case control study was conducted among the 106 cases with NAFLD and 212 unmatched hospital-based controls without having NAFLD. A case was defined based on the presence of fatty liver according to the diagnostic ultrasonographic criteria. Those were increase echogenicity of the liver compared to kidney and spleen, obliteration of vascular architecture, and deep attenuation of ultrasonic signals. There should be at least two out of three criteria to diagnosed as NAFLD. The data was collected by using an interviewer-administered questionnaire. The risk factors were determined by using multiple logistic regression and the results were interpreted by using adjusted odds ratio (AOR) and $95 \%$ confidence interval $(95 \% \mathrm{Cl})$.

Results: The risk factors for NAFLD were found as the fast food consumption more than 1 time per week (AOR=9.34, 95\% Cl=4.47-19.49), none consumption of coffee ( $A O R=2.78,95 \% \mathrm{Cl}=2.78-1.32)$, family history of liver disease (AOR=12.2, 95\% $\mathrm{Cl}=2.16-67.97)$, methotrexate usage (AOR=32.02, 95\% $\mathrm{Cl}=1.45-$ 707.29), inadequate physical activity ( $A O R=8.10,95 \% \mathrm{Cl}=4.04-16.26)$, high $\mathrm{BMI}$ value more $\geq 23 \mathrm{Kg} / \mathrm{m}^{2}$ $(A O R=6.17,95 \% \mathrm{Cl}=2.93-12.99)$ Being a Sinhalese (AOR=12.7, 95\% $\mathrm{Cl}=2.03-79.33)$.

Conclusion: There were seven independent risk factors for NAFLD were identified. Among those, most of the risk factors were modifiable risk factors such as inadequate physical activity, High BMI value ( $\geq$ $23 \mathrm{Kg} / \mathrm{m}^{2}$ ) with overweight, infrequent coffee consumption, and increase fast-food consumption. It should be taken primary preventive strategies for those modifiable risk factors to prevent NAFLD.

\section{Introduction}

The fatty liver disease is the condition that results due to the accumulation of fat in the liver cells. The rate of fat deposition is depending on the balance between fat accumulation and the removal of fat from the liver cells. Non-alcoholic fatty liver disease (NAFLD) is the fat accumulation in the hepatic cells without damaging hepatic cells. There are no causes for secondary fat accumulation such as alcohol consumption, uses of steatogenic medications, and hereditary disorder such as hemochromatosis. The active form of this NAFLD was Steatohepatitis. It can progress to cirrhosis or its complications and leads to increase in premature death due to cardiovascular diseases. ${ }^{1}$

A review reported that the global prevalence of NAFLD is $25.24 \%{ }^{2}$ The prevalence of NAFLD was $13.5 \%$ in Africa and $31.8 \%$ in the Middle East and $30.4 \%$ South America. ${ }^{1}$ Another study in the United States showed that the NAFLD prevalence varied from $27-34 \% .{ }^{3}$ The prevalence of NAFLD among the Asian population was ranged from $5-40 \%$ based on ultra-sonographic study. ${ }^{4}$ One Sri Lankan study reported 
that the prevalence of NAFLD was $18 \%$ in $2011 .{ }^{5}$ However, the true prevalence was still unknown because of the lack of reliable tests for the diagnosis. ${ }^{6}$

The major risk factors for NAFLD were metabolic factors such as obesity, dyslipidemia, hypertension, and diabetic Mellitus. ${ }^{(7-11)}$ Furthermore, the socio-demographic risk factors such as old age, ethnicity, and being male sex, a higher level of education, higher income level, low physical activity were also recognized as the risk factors for NAFLD. $(4,5,8,10)$ One study indicated that the hematocrit level significantly associated with fibrosis in NAFLD in patients in Europe. ${ }^{12}$ There was a hypothesis that increases hemoglobin level is associated with NAFLD. ${ }^{13}$

Most of the patients with fatty liver disease were asymptomatic and they were only diagnosed by ultrasonography at their health checkups. Focusing on the recent disease pattern in Sri Lanka, noncommunicable diseases were more common compare the communicable diseases due to practicing unhealthy lifestyles such as lack of exercise and an unhealthy diet. Further, the costs associated with the medical care for NAFLD are very high, especially at first diagnosis. ${ }^{14}$ The objective of the study was to determine the risk factors for NAFLD among the patients admitted to a tertiary care Hospital in Sri Lanka.

\section{Methods}

This was a hospital-based unmatched case control study, conducted in the largest tertiary care hospital in Gampaha district during the period of 1st of June to 31st of August 2019. The hospital has four medical wards, five surgical wards, and three obstetrics and gynecology wards. The case group was the patients admitted to Medical, Surgical, and Gynecology wards and who were newly diagnosed to have fatty liver disease or diagnosed as a fatty liver disease within the last 6 months or less by ultrasonography.

NAFLD was diagnosed based on the presence of fatty liver according to established ultrasound criteria which were increase echogenicity of the liver compared to kidney and spleen, obliteration of vascular architecture, and deep attenuation of ultrasonic signals. Presences of two out of above three criteria were taken to diagnose as NAFLD. ${ }^{15}$ It was diagnosed by four well-trained medicals officers at the radiology department in the hospital. The control group was the patients admitted to the same units and who were not diagnosed as a fatty liver disease by ultrasonography. The exclusion criteria for both cases and controls were the patients who consumed alcohol above the safe limit among current drinkers and formal drinkers, pregnant women, pediatric age groups ( $\leq 14$ years of age), patients who were diagnosed as hepatitis, cirrhosis, liver metastasis and liver cancers, cholestasis, alcoholic liver disease, and dengue hemorrhagic fever.

Sample size calculation was done based on odds ratio as 1.96 for elevated triglyceride for NAFLD, ${ }^{11}$ the anticipated proportion of elevated triglyceride among controls as $46 \%$, power as $80 \%$, and with $5 \%$ significant level. The control per case ratio was 2:1. According to the calculation, a minimum of 101 cases and 202 controls were needed. After adding $5 \%$ for the non-responders, it was decided to recruit 
106 cases and 212 controls. Those who full fill inclusion criteria were recruited consecutively until the required sample size was achieved.

The study instruments were a pre-tested interviewer-administered questionnaire (IAQ) and a record sheet. The IAQ has three parts; part 1- assessed socio-demographic risk factors, part 2- assessed medical risk factors, and part 3- assessed other risk factors (family history of liver disease, Frequency of Tea, Coffee, and Fast food consumption, Physical activity level, Alcohol consumption, Methotrexate usage. The face and content validity of the questionnaire was assured. The validated global physical activity questionnaire (GPAQ) was used to access the physical activity levels. ${ }^{16}$ The validity of the GPAQ ranged from low to moderately high $(r=0.25-0.63) .{ }^{17}$ Pretesting was done at another hospital of a radiology unit with the patients who were attended to abdominal ultrasound scan. The record sheet was used to record the hemoglobin level, height, weight. The height was measured by using a standard measuring tape. The weight was measure by using a calibrated scale.

Data collection was done at the Radiology department of the hospital by the first author. Because all the admitted patients also send for scans to the radiology department and it was done by four trained medical officers. Therefore, with the help of the radiology medical officers, it could get relatively more accurate information whether the patients had or had not fatty Liver Disease. Before the data collection, obtained permission from the consultant radiologists in the Radiology department. An ultrasound scan was done using $5 \mathrm{MHz} 50 \mathrm{~mm}$ convex probe which was made in china.

The safe limit of alcohol consumption was assessed based on Asian standard values which were 14 units per week per men and 7 units per week for women. ${ }^{18}$ One unit of alcohol was included in the 25$30 \mathrm{ml}$ of arrack or whiskey, $50 \mathrm{ml}$ of illicit alcohol, a half-pint of beer or toddy, $175 \mathrm{ml}$ glass of wine. Those were taken into account for calculating units of alcohol per week. ${ }^{18}$ Hypertension, diabetic Mellitus, and dyslipidemia status were cross-checked with the BHTs.

Body Mass Index (BMI) for Asian cut off value was taken as a BMI of $\geq 23 \mathrm{Kg} / \mathrm{m} 2$ as overweight in this study. ${ }^{19}$ The physical activity level was assessed by using mainly three types of activities as the activity at work, travel to and from places, recreational activities. It was calculated by using Metabolic Equivalent (MET). In typical week, adequacy of exercises asses as by using Moderate intensity physical activity of 150 minutes or Vigorous-intensity activity of 75 minutes or combination of moderate and vigorousintensity physical activity achieving at least $600 \mathrm{MET}$ minutes. MET minutes were calculated in a case of combined activity as follows. Moderate intensity activity MET min/week equals 4.0*Moderate intensity activity minutes*Moderate activity days, Vigorous-intensity activity MET min/week equals 8.0*Vigorous intensity activity minutes* Vigorous-intensity activity days and walking/cycling MET min/week equals $3.3^{*}$ walking/cycling minutes*Walking/Cycling days" ${ }^{16}$ If the participant not fulfilled the above criteria was taken as inadequately physical activity level.

The cutoff of tea cups consumption was taken as $>4$ cups per day and $\leq 4$ cups per day and for the coffee, consumption was taken as $\geq 1$ cups per day or none use per day. ${ }^{11,20}$ The fast foods were 
considered as cakes, snacks, bread, instant noodles, processed fish and meat, buns, pastries, hot dogs, etc. The cut off for fast food consumption was taken as $>1$ time and the $\leq 1$ time per week. ${ }^{21}$ The average hemoglobin value among the Asian women was 11 to $13 \mathrm{~g} / \mathrm{dl}$ and among men, it was 13 to $15 \mathrm{~g} / \mathrm{dl}$. Therefore, the cut off value was taken as $>13 \mathrm{~g} / \mathrm{dl}$ for females and $>15 \mathrm{for}$ males. The family history of liver disease was considered as if any family member from a maternity or paternity side had suffered from any kind of a liver disease condition such as fatty liver, cirrhosis, NASH, etc.

The statistical analysis was done by using SPSS 16 version. The results were interpreted by using the odds ratios (OR), 95\% confident intervals $(95 \% \mathrm{Cl})$, and the $p$ values. The variables with $p$-value $<0.2$ in the bivariate analysis were selected for the multiple logistic regression. The purposeful selection was used to perform. Hosmer and Lemeshow test was used as the test for goodness of fit and it was observed as satisfactory (chi-square $4.48, p$ value $=0.61$ )

The permission was taken from the Director of the hospital and the consultants. The interview was conducted after obtaining the informed written consent of the patients. Measures were taken to minimize the disturbances to the routine ward works. The data collection was done by avoiding the routine daily ward round times. Ethical clearance was taken from the Ethics Review Committee at the Postgraduate Institute of Medicine, Colombo.

\section{Results}

The mean age of the study population was 46.46 years with SD of 15 . The range was 58 years which spanned between the minimum age of 17 years to a maximum age of 75 years. The male population among the cases was $60.4 \%(n=64)$ and among the controls, it was $45.8 \%(n=97)$. Most of the participants were Sinhala $(n=297,93.4 \%)$ and Buddhist $(n=210,66.0 \%)$. Among the study population, $250(78.6 \%)$ participants were married and the 68(21.4\%) subjects were single.

There were statistically significant positive associations between the male gender, being a Sinhalese, higher income level, higher educational level, and NAFLD. (Table 1) 
Table 1

Association between socio-demographic factors and NAFLD

\begin{tabular}{|c|c|c|c|c|c|}
\hline & \multicolumn{2}{|c|}{ Cases } & \multicolumn{2}{|c|}{ Controls } & \multirow{2}{*}{$\begin{array}{l}\text { OR } \\
95 \% \mathrm{Cl} \\
\text { P value }\end{array}$} \\
\hline & $\mathrm{n}$ & $\%$ & $\mathrm{n}$ & $\%$ & \\
\hline \multirow{2}{*}{$\begin{array}{l}\text { Male } \\
\text { Female }\end{array}$} & 64 & $60.4 \%$ & 97 & $45.8 \%$ & \multirow{2}{*}{$\begin{array}{l}\mathrm{OR}=1.81 \\
95 \% \mathrm{Cl}=1.12-2.90 \\
\mathrm{p} \text { value }=0.014\end{array}$} \\
\hline & 42 & $39.6 \%$ & 115 & $54.2 \%$ & \\
\hline \multirow{2}{*}{$\begin{array}{l}\text { Age }>45 \text { Years } \\
\text { Age } \leq 45 \text { Years }\end{array}$} & 57 & $53.8 \%$ & 119 & $56.1 \%$ & \multirow{2}{*}{$\begin{array}{l}\mathrm{OR}=0.91 \\
95 \% \mathrm{Cl}=0.57-1.45 \\
\mathrm{p} \text { value }=0.690\end{array}$} \\
\hline & 49 & $46.2 \%$ & 93 & $43.9 \%$ & \\
\hline \multirow{2}{*}{$\begin{array}{l}\text { Currently Employed } \\
\text { Currently Non-Employed }\end{array}$} & 64 & $60.4 \%$ & 105 & $49.5 \%$ & \multirow{2}{*}{$\begin{array}{l}\mathrm{OR}=1.55 \\
95 \% \mathrm{Cl}=0.97-2.50 \\
\mathrm{p} \text { value }=0.068\end{array}$} \\
\hline & 42 & $39.6 \%$ & 107 & $50.5 \%$ & \\
\hline \multirow{2}{*}{$\begin{array}{l}\text { Sinhalese } \\
\text { Non-Sinhalese }\end{array}$} & 104 & $98.1 \%$ & 193 & $91.0 \%$ & \multirow{2}{*}{$\begin{array}{l}\mathrm{OR}=5.12 \\
95 \% \mathrm{Cl}=1.17-22.4 \\
\mathrm{p} \text { value }=0.017\end{array}$} \\
\hline & 2 & $1.9 \%$ & 19 & $9.0 \%$ & \\
\hline \multirow{2}{*}{$\begin{array}{l}\text { Buddhist } \\
\text { Non-Buddhist }\end{array}$} & 74 & $69.8 \%$ & 136 & $64.2 \%$ & \multirow{2}{*}{$\begin{array}{l}\mathrm{OR}=1.92 \\
95 \% \mathrm{Cl}=0.78-2.13 \\
\mathrm{p} \text { value }=0.315\end{array}$} \\
\hline & 32 & $30.2 \%$ & 76 & $35.8 \%$ & \\
\hline $\begin{array}{l}\text { Income Rs. } \geq 10,000 \\
<10,000\end{array}$ & 92 & $86.8 \%$ & 164 & $77.4 \%$ & $\begin{array}{l}\mathrm{OR}=1.92 \\
95 \% \mathrm{Cl}=1.01-3.68 \\
\mathrm{p} \text { value }=0.045\end{array}$ \\
\hline $\begin{array}{l}\text { Married } \\
\text { Unmarried }\end{array}$ & 20 & $81.1 \%$ & 164 & $77.4 \%$ & $\begin{array}{l}\mathrm{OR}=1.26 \\
95 \% \mathrm{Cl}=0.70-2.25 \\
\mathrm{p} \text { value }=0.439\end{array}$ \\
\hline \multirow[t]{2}{*}{$\begin{array}{l}\text { Educational level }>0 / L \\
\leq O / L\end{array}$} & $\begin{array}{l}38 \\
68\end{array}$ & $\begin{array}{l}35.8 \% \\
64.2 \%\end{array}$ & 160 & $\begin{array}{l}24.5 \% \\
75.5 \%\end{array}$ & $\begin{array}{l}\mathrm{OR}=1.72 \\
95 \% \mathrm{Cl}=1.04-2.85\end{array}$ \\
\hline & & & & & $p$ value $=0.035$ \\
\hline
\end{tabular}




\begin{tabular}{|c|c|c|c|c|c|}
\hline & \multicolumn{2}{|c|}{ Cases } & \multicolumn{2}{|c|}{ Controls } & \multirow{2}{*}{$\begin{array}{l}\text { OR } \\
95 \% \mathrm{Cl}\end{array}$} \\
\hline & $\mathrm{n}$ & $\%$ & $n$ & $\%$ & \\
\hline Total & 106 & $100 \%$ & 212 & $100 \%$ & $P$ value \\
\hline
\end{tabular}

There were statistically significant positive associations between the presence of a family history of liver diseases, the use of methotrexate, higher hemoglobin level, and NAFLD. (Table 2) 
Table 2

Association between medically related factors and NAFLD

\begin{tabular}{|c|c|c|c|c|c|}
\hline \multirow[t]{2}{*}{ Medically related factors } & \multicolumn{2}{|c|}{ Cases } & \multicolumn{2}{|c|}{ Controls } & \multirow{2}{*}{$\begin{array}{l}\text { OR } \\
95 \% \mathrm{Cl} \\
\mathrm{P} \text { value }\end{array}$} \\
\hline & $\mathrm{n}$ & $\%$ & n & $\%$ & \\
\hline \multirow{3}{*}{$\begin{array}{l}\text { Hypertension } \\
\text { Yes } \\
\text { No }\end{array}$} & 24 & $22.6 \%$ & 52 & $24.5 \%$ & \multirow{3}{*}{$\begin{array}{l}\mathrm{OR}=0.90 \\
95 \% \mathrm{Cl}=0.52-1.56 \\
\mathrm{p} \text { value }=0.710\end{array}$} \\
\hline & \multirow[b]{2}{*}{82} & \multirow[b]{2}{*}{$77.4 \%$} & \multirow[b]{2}{*}{160} & \multirow[b]{2}{*}{$75.5 \%$} & \\
\hline & & & & & \\
\hline \multirow{2}{*}{$\begin{array}{l}\text { Diabetes Mellitus Yes } \\
\text { No }\end{array}$} & 28 & $26.4 \%$ & 45 & $21.2 \%$ & \multirow{2}{*}{$\begin{array}{l}\mathrm{OR}=1.33 \\
95 \% \mathrm{Cl}=0.77-2.29 \\
\mathrm{p} \text { value }=0.30\end{array}$} \\
\hline & 78 & $73.6 \%$ & 167 & $78.8 \%$ & \\
\hline \multirow{2}{*}{$\begin{array}{l}\text { Hyperlipidemia } \\
\text { Yes } \\
\text { No }\end{array}$} & 26 & $24.5 \%$ & 35 & $16.5 \%$ & \multirow{2}{*}{$\begin{array}{l}\mathrm{OR}=1.64 \\
95 \% \mathrm{Cl}=0.93-2.91 \\
\mathrm{p} \text { value }=0.087\end{array}$} \\
\hline & 80 & $75.5 \%$ & 177 & $83.5 \%$ & \\
\hline \multirow{2}{*}{$\begin{array}{l}\text { Family History of liver diseases Yes } \\
\text { No }\end{array}$} & 13 & $12.3 \%$ & 2 & $0.9 \%$ & \multirow{2}{*}{$\begin{array}{l}\mathrm{OR}=14.68 \\
95 \% \mathrm{Cl}=3.25-66.35 \\
\mathrm{p} \text { value }=<0.001\end{array}$} \\
\hline & 93 & $87.7 \%$ & 210 & $99.1 \%$ & \\
\hline \multirow{2}{*}{$\begin{array}{l}\text { Haemoglobin level } \\
\text { Higher } \\
\text { Lower }\end{array}$} & 37 & $34.9 \%$ & 55 & $25.9 \%$ & \multirow{2}{*}{$\begin{array}{l}\mathrm{OR}=1.53 \\
95 \% \mathrm{Cl}=0.92-2.53 \\
\mathrm{p} \text { value }=0.097\end{array}$} \\
\hline & 69 & $65.1 \%$ & 157 & $74.1 \%$ & \\
\hline \multirow{2}{*}{$\begin{array}{l}\text { Used methotrexate } \\
\text { Yes } \\
\text { No }\end{array}$} & 10 & $9.4 \%$ & 1 & $0.5 \%$ & \multirow{2}{*}{$\begin{array}{l}\mathrm{OR}=21.98 \\
95 \% \mathrm{Cl}=2.77-174.14 \\
\mathrm{p} \text { value }=<0.001\end{array}$} \\
\hline & 96 & $90.6 \%$ & 211 & $99.5 \%$ & \\
\hline Total & 106 & $100 \%$ & 212 & $100 \%$ & \\
\hline
\end{tabular}

There were statistically significant positive associations between $>4$ cups of tea per day, $\geq 1$ cup of coffee per day, consumption of fast food more than one time per week, engaging inadequate physical activities, BMI of $\geq 23 \mathrm{Kg} / \mathrm{m} 2$, consuming alcohol within the safe limit and the NAFLD. (Table 3 ) 
Table 3

Association between behavioral factors and NAFLD

\begin{tabular}{|c|c|c|c|c|c|}
\hline \multirow[t]{2}{*}{ Behavioral factors } & \multicolumn{2}{|c|}{ Cases } & \multicolumn{2}{|c|}{ Controls } & \multirow{2}{*}{$\begin{array}{l}\text { OR } \\
95 \% \mathrm{Cl} \\
\mathrm{P} \text { value }\end{array}$} \\
\hline & n & $\%$ & n & $\%$ & \\
\hline \multirow{2}{*}{$\begin{array}{l}\text { Inadequate physical activity } \\
\text { Adequate physical activity }\end{array}$} & 84 & $79.2 \%$ & 53 & $25 \%$ & \multirow{2}{*}{$\begin{array}{l}\mathrm{OR}=11.45 \\
95 \% \mathrm{Cl}=6.52-20.11 \\
\mathrm{P} \text { value }<0.001\end{array}$} \\
\hline & 22 & $20.8 \%$ & 159 & $75.0 \%$ & \\
\hline \multirow{2}{*}{$\begin{array}{l}\text { No of Teacups per day }>4 \text { cups } \\
\leq 4 \text { cups }\end{array}$} & 12 & $11.3 \%$ & 1 & $0.5 \%$ & \multirow{2}{*}{$\begin{array}{l}\mathrm{OR}=26.93 \\
95 \% \mathrm{Cl}=3.45-210.16 \\
\mathrm{p} \text { value }=<0.001\end{array}$} \\
\hline & 94 & $88.7 \%$ & 211 & $99.5 \%$ & \\
\hline \multirow{2}{*}{$\begin{array}{l}\text { No of Coffee cups per day: Not consumed } \\
\geq 1 \text { cup }\end{array}$} & 77 & $72.6 \%$ & 110 & $51.9 \%$ & \multirow{2}{*}{$\begin{array}{l}\mathrm{OR}=2.46 \\
95 \% \mathrm{Cl}=1.48-4.08 \\
\mathrm{P} \text { value }=<0.001\end{array}$} \\
\hline & 29 & $27.4 \%$ & 102 & $48.1 \%$ & \\
\hline \multirow{2}{*}{$\begin{array}{l}\text { Fast food Consumption per week }>1 \text { time } \\
\leq 1 \text { time }\end{array}$} & 76 & $71.7 \%$ & 49 & $23.1 \%$ & \multirow{2}{*}{$\begin{array}{l}\mathrm{OR}=8.42 \\
95 \% \mathrm{Cl}=4.96-14.31 \\
\mathrm{p} \text { value }=<0.001\end{array}$} \\
\hline & 30 & $28.3 \%$ & 163 & $76.9 \%$ & \\
\hline \multirow{2}{*}{$\begin{array}{l}\text { Alcohol within the safe limit } \\
\text { Never used }\end{array}$} & 49 & $46.2 \%$ & 64 & $30.2 \%$ & \multirow{2}{*}{$\begin{array}{l}\mathrm{OR}=1.98 \\
95 \% \mathrm{Cl}=1.23-3.21 \\
\mathrm{p} \text { value }=0.005\end{array}$} \\
\hline & 57 & $53.8 \%$ & 148 & $69.8 \%$ & \\
\hline \multirow{2}{*}{$\begin{array}{l}\mathrm{BMI} \\
\geq 23 \mathrm{Kg} / \mathrm{m}^{2} \\
<23 \mathrm{Kg} / \mathrm{m}^{2}\end{array}$} & 73 & $68.9 \%$ & 78 & $36.8 \%$ & \multirow{2}{*}{$\begin{array}{l}\mathrm{OR}=3.80 \\
95 \% \mathrm{Cl}=2.31-6.25 \\
\mathrm{p} \text { value }=<0.001\end{array}$} \\
\hline & 33 & $31.1 \%$ & 134 & $63.2 \%$ & \\
\hline Total & 106 & $100 \%$ & 212 & $100 \%$ & \\
\hline
\end{tabular}

As shown in Table 4, the fast-food consumption $>1$ time per week was a risk factor for NAFLD and it has 9.34 times more risk of getting NAFLD to compare to those who consume fast foods $\leq 1$ time per week. The none consumption of coffee was a risk factor for NAFLD and it has 2.78 times more risk of getting NAFLD among the none consumers of coffee compared to the coffee consumers. Therefore, coffee consumption was a protective factor for NAFLD. The inadequate exercise level also a risk factor for NAFLD. There was 8.10 times more risk of getting NAFLD among the people with inadequate physical 
activity level compared to those who were engaged adequate exercise level. The BMI of $\geq 23 \mathrm{Kg} / \mathrm{m}^{2}$ was a risk factor for NAFLD. It has 6.17 times more risk of getting NAFLD among the people with $\mathrm{BMI} \geq$ $23 \mathrm{Kg} / \mathrm{m}^{2}$ compared to $\mathrm{BMI}<23 \mathrm{Kg} / \mathrm{m}^{2}$. The family history of liver disease was a risk factor for NAFLD. There was a 12.22 times more risk of getting NAFLD among those who had a family history of liver disease compared to those who had not a family history of liver disease. Methotrexate usage was a risk factor for NAFLD. It has 32 times more risk of getting NAFLD among the methotrexate users to compare to none users. Being a Sinhalese also a risk factor for NAFLD. There was a 12.07 times more risk of getting NAFLD among the Sinhala ethnicity group compare to the non-Sinhala ethnicity group.

Table 4

The risk factors for NAFLD according to the multiple logistic regression

\begin{tabular}{|llllll|}
\hline Risk factors & B co-efficient & SE* $^{*}$ & AOR** & $\mathbf{9 5 \%}$ Cl*** & P value \\
\hline Fast Foods $>$ 1times/week & 2.23 & 0.37 & 9.34 & $4.47-19.49$ & $<0.001$ \\
\hline None use of coffee & 1.02 & 0.38 & 2.78 & $2.78-1.32$ & 0.007 \\
Inadequate physical activity & 2.09 & 0.35 & 8.10 & $4.04-16.26$ & $<0.001$ \\
\hline$\geq 23 \mathrm{Kg} / \mathrm{m}^{2} \mathrm{BMI}$ & 1.82 & 0.38 & 6.17 & $2.93-12.99$ & $<0.001$ \\
\hline Family history of Liver Disease & 2.50 & 0.88 & 12.22 & $2.16-68.97$ & 0.005 \\
\hline Methotrexate usage & 3.46 & 1.57 & 32.02 & $1.45-707.29$ & 0.028 \\
\hline Sinhalese ethnicity & 2.54 & 0.93 & 12.70 & $2.03-79.33$ & 0.007 \\
\hline *SE-Standard Error ${ }^{* *}$ AOR- Adjusted Odds Ratio ***Cl-Confident Interval & \\
\hline Hosmer and Lemeshow Test (Chi square value $=4.48$ p value $=0.61)$ & \\
\hline
\end{tabular}

\section{Discussion}

The risk factors for NAFLD were increase frequency of fast food consumption, none usage of coffee, inadequate exercise level, high BMI value $\geq 23 \mathrm{~kg} / \mathrm{m}^{2}$, family history of liver disease, usage of methotrexate, and being a Sinhalese.

In the present study, the increased frequency of fast food consumption had 9.4 times more risk of getting NAFLD to compare to less fast food consumers. The findings are compatible with past literature as well. ${ }^{21}$ One study reported that fast foods induced NAFLD in mice. ${ }^{22}$ A review reported that NAFLD patients have shown better outcomes with low carbohydrate and low-fat diet. ${ }^{23}$

There was 2.8 times more risk of getting NAFLD among those who not consume coffee compare to those who consume coffee. A systematic review revealed that coffee contains caffeine and it had a positive effect on the NAFLD. ${ }^{20}$ Another two studies reported that coffee consumption is associated with a significant reduction in the risk of fibrosis among NASH patients. ${ }^{24,25}$ Coffee reduces NAFLD 
prevalence. ${ }^{26}$ Several possible mechanisms underlying is that coffee includes anti-oxidative, antiinflammatory, and anti-fibrotic effects. ${ }^{26,27}$

There was 8.1 times more risk of getting NAFLD among the participants with less physical activity level compared to the participants who had adequate physical activity level. The findings are consistent with another study. ${ }^{28}$ One study reported that longer sitting time was associated with a higher prevalence of NAFLD. ${ }^{29}$ According to a randomized control trial, exercise programs reduced fatty liver index and NAFLDfibrosis score among the NAFLD patients. ${ }^{30}$ According to a meta-analysis, dose-dependent increase levels of physical activity leads to a reduced risk of NAFLD. ${ }^{31}$ Another case-control study found that among men physical activity was inversely associated with the risk of NAFLD in a dose-dependent manner. ${ }^{32} \mathrm{~A}$ review emphasized the independent effect of physical activity, including aerobic exercise in the treatment of NAFLD. ${ }^{33}$ Exercise increases fatty acid oxidation, decreases fatty acid synthesis, and prevents mitochondrial and hepatocellular damage. ${ }^{34}$

There was a 6.17 times more risk of getting NAFLD with a high BMI value $\left(\geq 23 \mathrm{Kg} / \mathrm{m}^{2}\right)$ compare to the low BMI value. Therefore, this study finding also consistent with the other findings where there was a statistically significant association of high BMI values with the NAFLD. ${ }^{5,21,35-38}$

In the present study, the family history of liver disease was found as a risk factor for NAFLD. It had a 12.2 times risk of getting NAFLD among the participants who had a family history of liver disease compared to the participants who did not have a family history of liver disease. Therefore, the findings were supported with the other findings as well. ${ }^{39,40}$ The methotrexate was a drug used to treat arthritis. Several studies showed that there was a statistically significant association between methotrexate usage and NAFLD. ${ }^{41,42}$

In the present study the high hemoglobin value, increase frequency of tea consumption, the safe limit of alcohol consumption, high-income level, high education level, and being a male were statistically significant associations with the NAFLD according to the bivariate analysis. In this present study, high hemoglobin value was not a risk factor for NAFLD. However, several studies reported that high hemoglobin value had a statistically significant association with NAFLD. ${ }^{43}$ According to the present study, higher income and higher educational levels were not risk factors for NAFLD. According to the two previous findings, there was a statistically significant association of high-income level with NAFLD 5,38 and higher education with the NAFLD. ${ }^{38}$

The diagnosis of the NAFLD mainly depended on the ultrasound scan. The gold standard method to diagnose NAFLD was a liver biopsy. Even though the sensitivity of a liver biopsy to diagnose fatty liver disease was $90 \%$ and the specificity was $90 \% .{ }^{44}$ Further, the sensitivity of ultrasound diagnosis of fatty liver disease was $71.7 \%$ and the specificity was $75.9 \% .{ }^{44}$ This is the major limitation of the study. Even though the most suitable representative sample for controls could be selected from the community, it was costly and time-consuming. This is another limitation. Recall bias is another inherent limitation of the 
case-control studies when assessing the exposures especially assessing physical activities and past history of liver diseases. Even though we excluded patients who consumed alcohol above the safe limit, their accuracy of the information may not be acceptable. The alcohol drinkers who take above the safe limit might be misclassified under safe drinkers as they might not tell the truth. In the present study hypertension, diabetic mellitus, and dyslipidemia were diagnosed by using the recent health records of the patients. Therefore, it might lead to misclassification of the disease conditions. It should be better to measure the value without using health records for diagnosing patients.

In conclusion, most of the risk factors for NAFLD were modifiable risk factors. Those were high frequency of fast food consumption, inadequate physical activity, high BMI value, none usage of coffee, usage of methotrexate. Awareness programs could be implemented at school, workplace, and community level as primary preventive measures.

\section{Declarations}

\section{Declarations}

Ethics approval and consent to participate - The Ethics Review Committee of the Postgraduate Institute of Medicine, Colombo granted ethical clearance. Informed written consent was obtained before data collection.

Consent for publication - Not applicable

Availability of data and materials - The datasets used and/or analyzed during the current study are available from the corresponding author on reasonable request.

Competing interest - "The authors declare that they have no competing interests" in this section.

Funding - Self-funded.

Authors' contributions - AN participated in the design of the study, coordinated data collection, and helped to draft the manuscript. CA participated in the design of the study, performed the statistical analysis, interpreted the data, performed the statistical analysis, and drafted the first version of the manuscript. All authors read and approved the final manuscript.

Acknowledgments - We are grateful to the Postgraduate Institute of Medicine, University of Colombo.

\section{References}

1. Iqbal U, Perumpail B, Akhtar D, Kim D, Ahmed A. The Epidemiology, Risk Profiling and Diagnostic Challenges of Nonalcoholic Fatty Liver Disease. Medicines. 2019;6(1):41.

2. Younossi ZM, Koenig AB, Abdelatif D, Fazel Y, Henry L, Wymer M. Global epidemiology of nonalcoholic fatty liver disease-Meta-analytic assessment of prevalence, incidence, and outcomes. 
Hepatology. 2016;64(1):73-84.

3. Review Team DR, LaBrecque DR, Abbas Z, Anania F, Ferenci P, Khan AG, et al. World Gastroenterology Organisation global guidelines: Nonalcoholic fatty liver disease and nonalcoholic steatohepatitis. J Clin Gastroenterol [Internet]. 2014;48(6):467-73. Available from: http://content.wkhealth.com/linkback/openurl?sid=WKPTLP:landingpage\&an=00004836900000000-98601\%0Ahttp://www.ncbi.nlm.nih.gov/pubmed/24921212.

4. 10.1016/S1665-2681(19)31922-2

Amarapurkar D, Kamani P, Patel N, Gupte P, Kumar P, Agal S, et al. Prevalence of non-alcoholic fatty liver disease: Population based study. Ann Hepatol [Internet]. 2007;6(3):161-3. Available from: http://dx.doi.org/10.1016/S1665-2681(19)31922-2.

5. Pinidiyapathirage M, Dassanayake AS, Rajindrajith S, Kalubowila U, Kato N, Wickremasinghe A, et al. Non-alcoholic fatty liver disease in a rural, physically active, low income population in Sri Lanka. BMC Res Notes. 2011;4:0-4.

6. Araújo AR, Rosso N, Bedogni G, Tiribelli C, Bellentani S. Global epidemiology of non-alcoholic fatty liver disease/non-alcoholic steatohepatitis: What we need in the future. Liver Int. 2018;38(November 2017):47-51.

7. Liu CJ. Prevalence and risk factors for non-alcoholic fatty liver disease in Asian people who are not obese. J Gastroenterol Hepatol. 2012;27(10):1555-60.

8. Cho HC. Prevalence and factors associated with nonalcoholic fatty liver disease in a nonobese Korean population. Gut Liver. 2016;10(1):117-25.

9. Amarapurkar DN, Hashimoto E, Lesmana LA, Sollano JD, Chen PJ, Goh KL. How common is nonalcoholic fatty liver disease in the Asia-Pacific region and are there local differences? J Gastroenterol Hepatol. 2007;22(6):788-93.

10. Schwimmer JB, Behling C, Newbury R, Deutsch R, Nievergelt C, Schork NJ, et al. Histopathology of pediatric nonalcoholic fatty liver disease. Hepatology. 2005;42(3):641-9.

11. Kato N, Pathmeswaran A, Rishikesawan V, Piyaratna C, Subasinghe CE, Niriella MA, et al. Incidence and risk factors for non-alcoholic fatty liver disease: A 7-year follow-up study among urban, adult Sri Lankans. Liver Int. 2017;37(11):1715-22.

12. Li G, Li Y, Liu L, Chen Y, Hu X, Wang J, et al. Elevated hematocrit in nonalcoholic fatty liver disease: A potential cause for the increased risk of cardiovascular disease? Clin Hemorheol Microcirc. 2012;51(1):59-68.

13. Yilmaz Y. Is nonalcoholic fatty liver disease the hepatic expression of the metabolic syndrome? World J Hepatol. 2012;4(12):332-4.

14. Allen AM, Van Houten HK, Sangaralingham LR, Talwalkar JA, McCoy RG. Healthcare Cost and Utilization in Nonalcoholic Fatty Liver Disease: Real-World Data From a Large U.S. Claims Database. Hepatology. 2018;68(6):2230-8.

15. Younossi ZM, Mullen KD, Cooper JN, Ong JP, Hurley M, Saadeh S, et al. The utility of radiological imaging in nonalcoholic fatty liver disease. Gastroenterology. 2002;123(3):745-50. 
16. Guide A. WHO Global physical activity Analysis Guide. 2016;14-5.

17. Herrmann SD, Heumann KJ, Der Ananian CA, Ainsworth BE. Validity and reliability of the global physical activity questionnaire (GPAQ). Meas Phys Educ Exerc Sci. 2013;17(3):221-35.

18. Katulanda P, Ranasinghe C, Rathnapala A, Karunaratne N, Sheriff R, Matthews D. Prevalence, patterns and correlates of alcohol consumption and its' association with tobacco smoking among Sri Lankan adults: A cross-sectional study. BMC Public Health. 2014;14(1):1-10.

19. Lim JU, Lee JH, Kim JS, Hwang Y, II, Kim TH, Lim SY, et al. Comparison of World Health Organization and Asia-Pacific body mass index classifications in COPD patients. Int J COPD. 2017;12:2465-75.

20. 10.1016/j.clnu.2016.03.012

Marventano S, Salomone F, Godos J, Pluchinotta F, Del Rio D, Mistretta A, et al. Coffee and tea consumption in relation with non-alcoholic fatty liver and metabolic syndrome: A systematic review and meta-analysis of observational studies. Clin Nutr [Internet]. 2016;35(6):1269-81. Available from: http://dx.doi.org/10.1016/j.clnu.2016.03.012.

21. 10.1053/j.gastro.2010.09.038

Williams CD, Stengel J, Asike MI, Torres DM, Shaw J, Contreras M, et al. Prevalence of nonalcoholic fatty liver disease and nonalcoholic steatohepatitis among a largely middle-aged population utilizing ultrasound and liver biopsy: A prospective study. Gastroenterology [Internet]. 2011;140(1):124-31. Available from: http://dx.doi.org/10.1053/j.gastro.2010.09.038.

22. Kim TH, Choi D, Kim JY, Lee JH, Koo SH. Fast food diet-induced non-alcoholic fatty liver disease exerts early protective effect against acetaminophen intoxication in mice. BMC Gastroenterol. 2017;17(1):1-8.

23. Riazi K, Raman M, Taylor L, Swain MG, Shaheen AA. Dietary patterns and components in nonalcoholic fatty liver disease (NAFLD): What key messages can health care providers offer? Nutrients. 2019;11(12):1-17.

24. Molloy JW, Calcagno CJ, Williams CD, Jones FJ, Torres DM, Harrison SA. Association of coffee and caffeine consumption with fatty liver disease, nonalcoholic steatohepatitis, and degree of hepatic fibrosis. Hepatology. 2012;55(2):429-36.

25. $10.1016 /$ j.trsl.2014.10.008

Zelber-Sagi S, Salomone F, Webb M, Lotan R, Yeshua H, Halpern Z, et al. Coffee consumption and nonalcoholic fatty liver onset: A prospective study in the general population. Transl Res [Internet]. 2015;165(3):428-36. Available from: http://dx.doi.org/10.1016/j.trsl.2014.10.008.

26. Chen S, Teoh NC, Chitturi S, Farrell GC. Coffee and non-alcoholic fatty liver disease: Brewing evidence for hepatoprotection? J Gastroenterol Hepatol. 2014;29(3):435-41.

27. Salomone F, Galvano F, Volti GL. Molecular bases underlying the hepatoprotective effects of coffee. Nutrients. 2017;9(1):1-13.

28. Jang L, Lee K. Independent Association of Physical Activity with Nonalcoholic Fatty Liver Disease and Alanine Aminotransferase Levels. J Clin Med. 2019;8(7):1013. 
29. Wei $\mathrm{H}, \mathrm{Qu} \mathrm{H}$, Wang $\mathrm{H}$, Deng $\mathrm{H}$. Associations between sitting time and non-alcoholic fatty liver diseases in Chinese male workers: a cross-sectional study. BMJ Open. 2016;6(9):e011939.

30. $10.1038 /$ srep36783

Dong F, Zhang Y, Huang Y, Wang Y, Zhang G, Hu X, et al. Long-term lifestyle interventions in middleaged and elderly men with nonalcoholic fatty liver disease: A randomized controlled trial. Sci Rep [Internet]. 2016;6(221):1-8. Available from: http://dx.doi.org/10.1038/srep36783.

31. Soiza RL, Donaldson AIC, Myint PK. Vaccine against arteriosclerosis: an update. Ther Adv Vaccines. 2018;9(6):259-61.

32. Li YF, He F, He Y, Pan XT, Wu YL, Hu ZJ, et al. Dose-response association between physical activity and non-alcoholic fatty liver disease: A case-control study in a Chinese population. BMJ Open. 2019;9(3).

33. Zelber-Sagi S, Godos J, Salomone F. Lifestyle changes for the treatment of nonalcoholic fatty liver disease: A review of observational studies and intervention trials. Therap Adv Gastroenterol. 2016;9(3):392-407.

34. Van Der Windt DJ, Sud V, Zhang H, Tsung A, Huang $H$. The effects of physical exercise on fatty liver disease. Gene Expr. 2018;18(2):89-101.

35. Ma H, Xu CF, Shen Z, Yu CH, Li YM. Application of Machine Learning Techniques for Clinical Predictive Modeling: A Cross-Sectional Study on Nonalcoholic Fatty Liver Disease in China. Biomed Res Int. 2018;2018.

36. Fan R, Wang J, Du J. Association between body mass index and fatty liver risk: A dose-response analysis. Sci Rep. 2018;8(1):1-7.

37. 10.1016/j.jceh.2017.05.005

Singh A, Parida S, Narayan J, Nath P, Padhi PK, Pati GK, et al. Simple Anthropometric Indices are Useful for Predicting Non-alcoholic Fatty Liver Disease [NAFLD] in Asian Indians. J Clin Exp Hepatol [Internet]. 2017;7(4):310-5. Available from: http://dx.doi.org/10.1016/j.jceh.2017.05.005.

38. Alam S, Fahim SM, Chowdhury MAB, Hassan MZ, Azam G, Mustafa G, et al. Prevalence and risk factors of non-alcoholic fatty liver disease in Bangladesh. JGH Open. 2018;2(2):39-46.

39. Loomba R, Abraham M, Unalp A, Wilson L, Lavine J, Doo E, et al. Association between diabetes, family history of diabetes, and risk of nonalcoholic steatohepatitis and fibrosis. Hepatology. 2012;56(3):943-51.

40. Sookoian S, Pirola CJ. Genetic predisposition in nonalcoholic fatty liver disease. Clin Mol Hepatol. 2017;23(1):1-12.

41. Labadie JG, Jain M. Noninvasive Tests to Monitor Methotrexate-Induced Liver Injury. Clin Liver Dis. 2019;13(3):67-71.

42. Sakthiswary R, Chan GYL, Koh ET, Leong KP, Thong BYH. Methotrexate-associated nonalcoholic fatty liver disease with transaminitis in rheumatoid arthritis. Sci World J. 2014;2014.

43. Juárez-Hernández E, Chávez-Tapia NC, Brizuela-Alcántara DC, Uribe M, Ramos-Ostos MH, NuñoLámbarri N. Association between serum hemoglobin levels and non alcoholic fatty liver disease in a 
mexican population. Ann Hepatol. 2018;17(4):577-84.

44. Sumida Y, Nakajima A, Itoh Y. Limitations of liver biopsy and non-invasive diagnostic tests for the diagnosis of nonalcoholic fatty liver disease/nonalcoholic steatohepatitis. World J Gastroenterol. 2014;20(2):475-85. 